İşletme Akademisi Dergisi
$2020,1(1): 34-55$

Araştırma Makalesi

\title{
Finansal Okuryazarlık Düzeyinin Bireylerin Tasarruf Eğilimi Üzerindeki Etkisi: Kırıkkale Üniversitesi Akademik ve İdari Personeli Üzerine Bir Araştırma ${ }^{1}$
}

\author{
Mehdi OKTAY \\ Kırıkkale Üniversitesi, Sosyal Bilimler Enstitüsü \\ mehdioktayy@gmail.com, www.orcid.org/0000-0002-1601-8040 \\ Dr. Öğr. Üyesi İlkut Elif KANDİL GÖKER \\ Kırıkkale Üniversitesi, İ̈BF, İşletme Bölümü, Muhasebe ve Finansman ABD \\ elifkandil@kku.edu.tr, www.orcid.org/0000-0002-5290-3514
}

\section{Öz}

$\mathrm{Bu}$ araştırma, finansal okuryazarlık düzeyinin bireylerin tasarruf eğilimi üzerindeki etkisini incelemek amacıyla yapılmıştır. Bu kapsamda Kırıkkale Üniversitesi bünyesindeki fakülteler ve yüksekokullarda görev yapmakta olan 438 akademik ve idari personele anket uygulanmıştır. Bu çalışma ile Kırıkkale Üniversitesi akademik ve idari personelinin finansal okuryazarlık düzeyleri tespit edilmiş, finansal okuryazarlık düzeyleri ile yaş, cinsiyet, unvan, eğitim düzeyi ve gelir gibi demografik özellikler arasında frekans analizleri yapılmıştır. Bununla birlikte katılımcların temel seviyede finansal okuryazarlık durumu ve ileri düzeyde finansal okuryazarlık durumu ile tasarruf eğilimleri arasında anlamlı bir ilişki olup olmadığı Pearson Ki Kare Testi ile analiz edilmiş; elde edilen bulgulara göre temel düzey ve ileri düzey finansal okuryazarlık düzeyi ile tasarruf eğilimi arasında anlamlı bir ilişki olduğu tespit edilmiştir.

Anahtar Kelimeler: Finansal Okuryazarlık, Finansal Eğitim, Finansal Bilgi, Tasarruf

Makale Gönderme Tarihi: 19.02.2020

Makale Kabul Tarihi: 13.03.2020

\footnotetext{
${ }^{1}$ Bu çalışma, Kırıkkale Üniversitesi Sosyal Bilimler Enstitüsü İşletme Anabilimdalı'nda Dr. Öğr. Üyesi İlkut Elif KANDİL GÖKER danışmanlığında Mehdi OKTAY tarafından hazırlanan yüksek lisans tezinden üretilmiştir.
}

\section{Önerilen Atıf:}

Oktay, M. ve Kandil Göker, İ.E., (2020). Finansal Okuryazarlık Düzeyinin Bireylerin Tasarruf Eğilimi Üzerindeki Etkisi: Kırıkkale Üniversitesi Akademik ve İdari Personeli Üzerine Bir Araştırma, İşletme Akademisi Dergisi, 1(1): 34-55.

(c) 2020 İşletme Akademisi Dergisi. 


Journal of Business Academy
$2020,1(1): 34-55$
DOI:10.26677/TR1010.2020.
Web pages: www.isakder.org

Research Article

\title{
The Impact of Financial Literacy on Individual Saving Behaviour: An Investigation on Academic and Administrative Staff of Kirıkkale University
}

\section{Mehdi OKTAY}

Kırıkkale University, Institüte of Social Sciences

mehdioktayy@gmail.com, www.orcid.org/0000-0002-1601-8040

\section{Assist. Prof. İlkut Elif KANDİL GÖKER}

Kırıkkale University, Faculty of Economics and Administrative Scineces

elifkandil@kku.edu.tr, www.orcid.org/0000-0002-5290-3514

\begin{abstract}
This study was carried out to examine the effect of financial literacy on the saving behaviour of individuals. In this context, 438 academic and administrative staff working in faculties and colleges within Kırıkkale University were surveyed. In this study, financial literacy levels of academic and administrative staff of Kurıkkale University were determined, and financial literacy levels and frequency, demographic factors such as gender, age, title, education level and income were analyzed. In addition to these, there is a significant correlation between the financial literacy of the participants and saving behaviour. It is determined that there is a significant relationship between basic level and advanced level of financial literacy and saving behaviour.
\end{abstract}

Keywords: Financial Literacy, Financial Education, Financial Information, Savings

Received: 19.02 .2020

Accepted: 13.03 .2020

\section{Suggested Citation:}

Oktay, M. and Kandil Göker, İ.E., (2020). The Impact of Financial Literacy on Individual Saving Behaviour: An Investigation on Academic and Administrative Staff of Kırıkkale University, Journal of Business Academy, 1(1): 34-55.

(C) 2020 Journal of Business Academy. 


\section{GİRIŞ}

Finansal okuryazarlık genel anlamda, insanların paralarını en verimli şekilde kullanabilmesi ve başarılı bir şekilde yönetebilmesini sağlamak için yeterli bilgiyi içselleştirebilme anlamına gelmektedir. Finansal okuryazarlı̆̆ın dört temel kavrama ilişkin olduğunu söylemek mümkündür. Bu kavramlar; gelir, harcama, servet ve borç olarak sıralanmaktadır. Gelir kavramı ile aylık maaş, ücret ya da bunların dışındaki herhangi bir getiri ifade edilirken; harcama ile alışverişler, vergiler, sigorta vb. konulardaki ödemeler ifade edilmektedir. Borç kavramı kredi kartları, bireysel kredi ve tüketici kredisi gibi taraflara olan yükümlülükleri, servet kavramı ise evler, arsalar ve beşerî sermayeyi ifade etmektedir. Bu kavramlara ilişkin gerekli bilgi birikiminin varlığı ve kararlılık içinde kullanımı durumuna da finansal okuryazarlık denilmektedir. Finansal okuryazarlık deyince akla gelen ilk şey para yönetimidir. Bireylerin kendi gelirini yönetmesi, iyi bir şekilde yatırım yapma, tasarruf yapma, bütçeyi yönetme anlamına gelmektedir. Bir başka tanımıyla finansal okuryazarlık bireylerin kendi ekonomisini yönetebilmesi mevcut ve potansiyel gelirleri ile giderlerini karşılayabilmesi demektir. Bir başka yaklaşımda finansal okuryazarlık parayı yönetmek, finansal ürün ve hizmetleri seçmek ve birikim yapmak olarak sıralanabilecek üç önemli başlık altında incelenmektedir.

Finansal okuryazarlık birey, tüketici ya da yatırımcı sıfatını haiz kişilerin yatırımlarını, etkili ve verimli bir karar alma süreci sonrasında gerçekleştirmesini sağlamaktadır. Finansal okuryazarlık bireysel yatırımcılar için olduğu kadar şirket yöneticileri için de çok büyük önem taşımaktadır. Şirket yöneticilerinin finansal konularda eğitim alması hususunda bir hassasiyet taşıması şirket çalışanlarını da ilgili konuda belirli bir bilgi düzeyinin üzerine taşımakta ve şirketin sürdürülebilirliğine katkı sağlamaktadır. Blalock vd. (2004) finansal okuryazarlığın yatırım, tasarruf, borçlarından yana rahatlama, kazandıklarından daha az harcama yapma, bir bütçeye bağlı yaşama ihtimalini arttırdığını ve bunun da iflas gibi durumları azaltıcı bir etkiye sahip olduğunu ifade etmiştir. Finansal okuryazarlık bono, tahvil ve hisse senetleri gibi pek çok sermaye piyasası aracının değerini belirleyen faktörlerdendir. Çünkü piyasa mekanizması ile fiyat oluşumunda talep tarafını oluşturan yatırımcıların finansal okuryazarlık düzeyleri yatırım kararlarını doğrudan etkileyecek ve bu durum da sermaye piyasası araçlarının gerçeğe yakın değerleri ile değerlenmelerine olanak tanıyacaktır.

Yapılan çalışmalara bakıldığında, dünyanın farklı ülkelerinde yaşayan tüketicilerin finansal bilgi altyapısı ile anlayışı noktasında yeteri kadar bilgi sahibi olmadıkları görülmektedir. Ekonomik İş Birliği ve Kalkınma Örgütü'ne (OECD) üye ülkeler ile OECD'ye üye olmayan ülkelerde yapılan kimi anketler tüketicilerin çok düşük düzeyde finansal kabiliyete sahip olduklarını göstermektedir. Bu durum bilgiye dayalı finansal kararlar verilmesini engellemekte, diğer taraftan finansal kabiliyet, okuryazarlık noktasında çoğunlukla yanlış fikirler ortaya konulmasına sebep olmaktadır. Bu bağlamda bireylerin fonlarını nasıl yönetmeleri gerektiğine yönelik eğitimlerin verilmesi önem arz etmektedir. Bu sayede bireylerin piyasada kendilerine sunulan geniş yelpazeli finansal hizmetler ile ürünler arasından doğru ve isabetli bir tercihte bulunabilmeleri ve ayrıca geleceğe hazırlık için birikim yapabilme becerisini sağlayıcı önlemlerin önceden alabilmeleri mümkün olabilmektedir.

\section{LITTERATÜR İNCELENMESİ}

Finansal okuryazarlık konusu ulusal yazında oldukça yoğun olarak ele alınmış bir konudur. Meslek, yaş, üniversitede okunan bölüm, akademik kariyer bazında farklı örneklemlere uygulanan anketler ile finansal okuryazarlık düzeyinin tespit edilmesi, ayrıca finansal okuryazarlık düzeyi ile demografik faktörler arasındaki ilişkilerin ortaya konulması amaçlanmıştır. 
Türkiye'de finansal yeterlilik üzerine yapılan önemli çalışmalardan biri Dünya Bankası ve SPK'nın 2012 yılında yapmış olduğu çalışmadır. Bu araştırma ile ülkelerin finansal okuryazarlık hususunda karşılaştırılması amaçlanmıştır. Ayrıca araştırmada Türk halkının finansal tutum, bütçe yönetimi ve borçlanma, davranış ve eğilimler, finansal planlama, finansal okuryazarlık, finansal ürün seçimi, katılımcıların sosyo-ekonomik durumu finansal bilgi edinimi ve ihtiyacı gibi finansal yeterlilikleri incelenmiştir. SPK'nın da destek verdiği bu araştırmada yüz yüze mülakat tekniği uygulanmıştır. Araştırmada Türkiye İstatistik Kurumu'nun (TÜIK) belirlemiş olduğu 12 farklı bölge, 40 il ve 142 ilçe olmak üzere, toplamda 3009 yetişkine yer verilmiştir. Ulaşılan sonuçlara bakıldığında, finansal okuryazarlık düzeyini tespit etmek üzere hazırlanan sorulara yönelik katılımcıların doğru cevap verme oranı ile katılımcıların gelir düzeyi arasında doğru bir orantının olduğu görülmüştür.

Riskleri doğru bir şekilde okuyabilmek, kendi risk yol haritasını belirlenmek ve yatırım kararları almak için memurların, işçilerin, serbest meslek sahiplerinin, tüketicilerin, iş adamlarının, akademisyenlerin, kadınların, gençlerin ve çocukların finansal okuryazarlığı öğrenebilmesi ve doğru bir biçimde kullanabilmelerinin bir ihtiyaç olduğu düşüncesinden hareketle 2012 yılının kasım ayından bu yana Türkiye'de faaliyet gösteren iki sivil toplum kuruluşu olan Finansal Okuryazarlık ve Erişim Derneği (FODER) kurulmuştur.

FODER'in hedefi finansal okuryazar hâline gelmiş bir Türkiye için ekosistem oluşturmak olarak belirlenmiştir. Bununla beraber özel sektör, devlet ve diğer sivil toplum örgütleri ile birlikte iş birliği içerisinde olan ülke çapındaki kişilerin, yatırımcıların, tüketicilerin finansal erişim ve finansal okuryazarlık farkındalıklarını oluşturabilmek, aynı zamanda araştırma, eğitim, bilinçlendirme uygulamalara destek biçiminde politikalar üretilmesini sağlayacak hususları da göz önünde bulundurmak, derneğin amaçları ve hedefleri arasında yer almaktadır.

Finansal okuryazarlık ve erişim derneğinin amacı ise \%50 olan bankacılık sistemine dâhil olmamış nüfusun diğer ülke standartlarına çekilmesi, araştırma, koordinasyon, uygulama ve denetleme çalışmaları yapmak amacıyla ulusal konseyin kurulması ve Türkiye'de finansal okuryazarlığın eğitim müfredatı içerisinde başlayarak kişilere ulaşması olarak belirlenmiştir. FODER'in kuruluş gayesi bireylerin, tüketicilerin, yatırımcıların, hane halkının tasarruf ile ilgili finansal okuryazarlığını ve bu büyük kitlenin farkındalığını ve bilincini artırma konusunda büyük bir önem ve görev arz etmektedir (http://www.fo-der.org, 05.06.2013).

Temizel ve Bayram (2010), çalışmalarında Anadolu Üniversitesi İktisadi ve İdari Bilimler Fakültesi öğrencilerinin temel düzeyde finansal okuryazarlık düzeylerini tespit etmeye çalışmışlardır. Öğrencilerin finansal durumlarını yönetmede kendilerini bulundukları seviyeden daha becerili ve başarılı olduklarını tespit etmişlerdir. Finansal okuryazarlık seviyesinin arttırılmasını sağlayacak programların eğitim ve öğretim müfredatlarında yer alması gerektiğini, finansal okuryazarlık hususunda yaygın bir eğitim sunabilecek internet ve sosyal medya gibi araçların kullanılmasının daha faydalı olacağını belirtmişlerdir.

Araz (2012) araştırmasında, finansal okuryazarlık ve kredi kartı sorunları arasındaki ilişkiyi iki aşamalı analiz ile açıklamaktadır. İlk aşamada, sıralı probit modeli ile kredi kartı kullanıcılarının karşılaştıkları finansal zorlukların nedenleri açıklanmakta ikinci aşamada ise ikili logit modeli ile kart temerrütlerinin vurgulayıcı nedenlerini açıklamaktadır. Açılayıcı değişkenler olarak da finansal okuryazarlık değişkenleri, kart sahiplerinin harcama eğilimleri, beklenmeyen durumlar, sosyo-ekonomik ve demografik değişkenler kullanılmıştır. Çalışmanın sonucunda, diş etkenlerin finansal zorunluluklarda önemli vurgulayıcılar olduğu belirlenmiş ve bireylerin finansal okuryazarlık seviyelerinin ve finansal eğitiminin yükseltilmesi durumunda kredi kartı sorunlarının azalacağı yönünde bir öngörüde bulunulmuştur. 
Saraç (2014), Dumlupınar Üniversitesi öğrencilerinden oluşan 797 öğrenci örnekleminde yaptığ çalışmada öğrencilerin finansal okuryazarlık düzeylerini ölçmeye çalışmıştır. Araştırmanın sonuçlarına göre, Dumlupınar Üniversitesi öğrencilerinin finansal okuryazarlıklarının düşük olduğu ve daha önce yapılan çalışmalara paralel olarak, öğrencilerin bu durumun farkında olmadıkları tespit edilmiştir. Okulda finans konusunda ders alan öğrencilerin hiç finans dersi görmemiş öğrencilere göre daha yüksek finansal okuryazarlığa sahip olduğu ifade edilmiştir.

Öztürk (2014) Süleyman Demirel Üniversitesi'nde çalışan akademik personel üzerinde yapmış olduğu bir anket çalışmasında, akademik personelin finansal davranış, finansal bilgi ve finansal tutum ile ilgili sorulara vermiş oldukları cevaplarla finansal okuryazarlıklarını belirlenmeye çalışmıştır. Buna göre akademik personelin temel düzeyde finansal açıdan okuryazar bireyler olduğu ancak ek finansal eğitime ihtiyaçları olduğu sonucu ortaya çıkmıştır.

Ergün vd. (2014), öğrencilerin finansal okuryazarlık seviyelerini belirlemek ve demografik özelliklerin finansal okuryazarlık ile ilişkili olup olmadığını incelemek üzere işletme öğrencileri üzerinde anket çalışması yapmış Ki-Kare Bağımsızlık Testi sonucunda öğrencilerin yalnızca temel seviyede finansal okuryazar olduklarını ve öğrencilerin okuldaki başarı düzeyleri ile aile bireylerine ait eğitim seviyelerinin finansal okuryazarlıkla ilişkisinin bulunmadığı ortaya koymuşlardır.

Çam ve Barut (2015), Gümüşhane Üniversitesi'nde okuyan ön lisans öğrencilerinin finansal okuryazarlık düzey ve davranışların araştırdıkları çalışmada; öğrencilerdeki finansal okuryazarlık düzeyinin düşük bulunduğunu ortaya koymuşlardır.

Fettahoğlu (2015), yapmış olduğu çalışmada finansal okuryazarlık düzeylerinin belirlenmesine çalışmış ve hane halkının aile bütçesinin yönetimi hususunda bilgi ve davranışlarının nasıl olduğunu belirlemeye çalışmıştır. Araştırmada Kocaeli ilinde ikamet eden 83 katılımcının cevapları değerlendirilmiştir. Bu katılımcılar tesadüfî örneklem yöntemine göre rastgele seçilmiştir. ANOVA ile analiz edilen verilerin ortaya koyduğu sonuca göre finansal okuryazarlık hususunda katılımcıların temel seviyede bilgilerinin olduğu ancak karmaşık ve bilgi gerektiren ürün, araç ve teknikler konusunda yetersizliklerin olduğu belirtilmiştir. Aynı zamanda hane halkı açısından yatırım işlevlerini tanıma ve yatırım yapma hususunda bilgi eksikliği olduğu, tahvil, yatırım fonu ve hisse senedi gibi menkul değerlerin kullanımının son derece düşük olduğu ortaya konulmuştur.

Güler (2015), Sakarya ilinde yaşayan 453 finansal tüketici üzerinde bir anket uygulaması yapmıştır. Çalışmanın sonuçlarına göre hane halkının yarıdan fazlasının son derece düşük seviyede finansal okuryazar olduğu ve finansal okuryazarlık seviyesi ile demografik özellikler ve tasarrufa yönelik davranış arasında anlamlı bir ilişki olduğu ortaya çıkmıştır. Bununla birlikte, borçlanma davranışı ile finansal okuryazarlık seviyesi arasında anlamlı herhangi bir ilişki bulunamamıştır.

Barmaki (2015), Hacettepe Üniversitesinde okuyan öğrencilerin finansal okuryazarlık seviyeleri, finansal davranış ile finansal tutumlarını ölçmüş, ayrıca finansal davranış ve finansal tutumları arasındaki ilişkiyi ortaya koymayı amaçlamıştır. 500 öğrenci üzerinde yapılan anket çalışmasında öğrencilerin finansal davranış, finansal okuryazarlık ve finansal tutum seviyeleri belirlenmiş ve ele alınan öğrenciler farklı demografik, sosyo-ekonomik ve tanımlayıcı özellikleri açısından incelenmiştir. Bu çalışmanın sonucunda öğrencilerin finansal okuryazarlığa ilişkin soruların $\% 53,62$ 'sine doğru cevap verdikleri dolayısıyla finansal okuryazarlık seviyelerinin orta düzeyde olduğu tespit edilmiştir. Öğrencilerin finansal okuryazarlıkla ilgili en fazla bilgiye sahip oldukları alanın temel para bilgisi olduğu görülmüş, en az bilgiye sahip oldukları alanın ise tasarruf ve yatırım alanı olduğu ortaya çıkmıştır. Bununla birlikte finansal okuryazarlık seviyesinin erkek öğrencilerde kız öğrencilere göre daha yüksek olduğunu ancak cinsiyet ile 
finansal okuryazarlık seviyesi arasında istatistiksel olarak anlamlı bir ilişki olmadığı sonucuna da varılmıştır. Öğrencilerin finansal okuryazarlık seviyesi ile sadece öğrenim gördükleri fakülte ve ana alan değişkenleri arasında istatistiksel olarak anlamlı bir ilişki olduğu tespit edilmiştir.

Özen ve Kaya (2015), Üniversite öğrencilerinin finansal okuryazarlık seviyesini ölçmek ve müfredattaki finansal içerikli derslerin finansal okuryazarlık düzeyi üzerinde etkili olup olmadığını araştırmayı hedefledikleri çalışmalarında 521 üniversite öğrencisini örneklem büyüklüğü olarak ele almıştır. Çalışmanın analiz sonuçlarına göre genel olarak öğrencilerin finansal okuryazarlık konusunda başarı düzeyi \%40,68 olarak bulunmuştur. Bu çalışma sonucunda eğitimin finansal okuryazarlık üzerinde etkili olduğu tespit edilmiştir. Çalışmanın önemli sonuçlarından bir diğeri ise öğrenciler arasında bayan öğrencilerin erkek öğrencilere göre finansal okuryazarlık düzeyinin daha yüksek olduğudur. Yazarlar elde ettikleri bulgulara göre finansal okuryazarlık düzeyinin arttırılması için müfredatlarına finans dersleri eklenebileceği önerisinde bulunmuşlardır.

Kılıç, vd. (2015) Gaziantep Üniversitesinde eğitim gören öğrenciler üzerinde bir araştırma yapmıştır. Üniversite öğrencilerinin finansal okuryazarlık düzeylerinin farklı demografik özellikleri açısından incelendiği bu çalışma sonucunda öğrencilerin finansal okuryazarlık ile ilgili sorularda genel olarak başarı düzeylerinin \% 48 olduğu görülmüştür. Erkek öğrencilerin bayan öğrencilere göre finansal okuryazarlık düzeyinin daha yüksek olduğu ortaya çıkmıştır. Ayrıca okuryazarlık düzeylerinde kredi kartı ve internet bankacılığı kullanımının etkili olduğu tespit edilmiştir. Öğrencilerin finansal okuryazarlık ile ilgili en çok bilgi sahibi oldukları hususun bireysel bankacılık konusu olduğu ve finansal okuryazarlık ile ilgili en az bilgiye sahip olduğu hususun ise yatırım konusu olduğu belirlenmiştir. Ayrıca bu çalışmanın sonucunda güncel finans bilgileri konusunda öğrencilerin daha fazla duyarlılığa sahip oldukları tespit edilmiştir.

Coşkun (2016), Manisa Celal Bayar Üniversitesi'nde öğrenim gören ön lisans öğrencilerinin finansal davranış ve tutumlarını finansal okuryazarlık düzeylerinin nasıl etkilediğini tespit edebilmek amacıyla hazırladığı ölçek üzerinden anket çalışması uygulamıştır. Araştırmanın neticesinde öğrencilerin finansal okuryazarlık seviyesinin \% 49,6 gibi bir oranla düşük olduğu sonucuna ulaşılmıştır.

Tuna ve Ulu (2016)'nun Sakarya Üniversitesi İşletme Fakültesi İşletme Bölümünde okuyan öğrencilerin tamamının katılmasıyla yaptıkları bir çalışmada, demografik özellikler açısından finansal okuryazarlık konusunda anlamlı bir farklılığın olup olmadığı araştırılmıştır. Cinsiyet açısından bakıldığında erkek öğrencilerin bayan öğrencilerden daha yüksek finansal okuryazarlık düzeyine sahip olduğu görülürken, yaş gurupları açısında bakıldı̆̆ında ise 23-25 yaş aralığında bulunan öğrencilerin finansal okuryazarlık seviyelerinin diğer yaş gruplarına göre daha yüksek olduğu sonucuna ulaşılmıştır.

Ünal ve Dülger (2015) finansal davranış eğilimlerini ortaya koymak ve finansal davranış eğilimlerinin etkilerini tespit etmek amacıyla Dumlupınar Üniversitesinin bütün bölümlerinde görev yapan akademik personelden 246'sına anket uygulamıştır. Araştırmanın sonucunda ankete katılan akademik personelin finansal gönenç durumlarından sınırlı düzeyde memnun oldukları ve finansal davranış eğiliminin finansal gönenç hali üzerinde pozitif yönlü bir etkisinin olduğu sonuçlarına ulaşılmıştır.

Kaya (2015) ele aldığ 1 çalışmada İzmir'de faaliyet gösteren KOBİ yöneticilerinin finansal okuryazarlık seviyelerini ölçmek istemiştir. Çalışma sonucunda KOBİ yöneticilerinin finansal okuryazarlık seviyesinin düşük olduğu tespit edilmiştir. 
Gutnu ve Cihangir (2015) Osmaniye Korkut Ata Üniversitesi akademik ve idari personelinin finansal okuryazarlık düzeyi, finansal okuryazarlık konusunda yeterli bilgi ve birikime sahip olup olmadıkları, bazı finansal kavramları bilme seviyeleri ve güncel finansal gelişmelere ilgi duyma durumlarını incelemiştir. Sonuçlar incelendiğinde bu kişilerin finansal kavramları çoğunlukla bildiğini tespit edilmiştir.

Karaağaç (2015) İstanbul Üniversitesi araştırma görevlilerinde finansal bilginin hangi alanlarda eksik olduğunu, finansal davranış ve tutumlarının neler olduğunu ve ne yönde olduğunu belirlemek, finansal okuryazar vasfına sahip olanların bu konuda ne gibi gelişmeler kaydedebileceği belirlemek amacıyla bir araştırma gerçekleştirmiştir. Araştırmanın sonucunda elde edilen verilerin, toplumun genelinde olduğu gibi araştırma görevlilerinde de finansal okuryazarlık düzeyinin düşük olduğu ortaya koyduğunu belirtmişlerdir.

Yardımcıŏglu ve Yörük (2016) finansal farkındalık ile finansal okuryazarlık durumları arasındaki ilişkiyi incelemek üzere tesadüfî örnekleme yoluyla Kahramanmaraş'ta çalışan kişileri temel alarak, 324 kişiden oluşan bir örneklem üzerinde araştırma yapmıştır. Yapılan analizler sonucunda finansal okuryazarlık ile finansal farkındalık arasında pozitif yönde bir ilişki olduğu tespit edilmiştir. Çalışanların finansal farkındalıkları arttıkça finansal okuryazarlıklarının da arttığı yönünde bulgular elde edilmiştir. Bununla birlikte çalışanların finansal farkındalık ve finansal okuryazarlık düzeylerinin arttırılması için finansal eğitimin önemli bir yere sahip olduğu ve finansal eğitimlerin artırılmasının çalışanlar için faydalı olacağ yönünde bir görüş bildirmişlerdir.

Şamiloğlu vd. (2016) Erciyes Üniversitesinde öğrenim gören 100 İşletme Bölümü öğrencisi ile yine aynı üniversitenin diğer bölümlerinde öğrenim gören 100 öğrenci olmak üzere toplamda 200 öğrenci üzerinde yapılan araştırma ile İşletme Bölümü öğrencilerinin bileşik faiz dışındaki bütün finansal tanımları diğer bölüm öğrencilerinden daha iyi bildiği sonucuna ulaşmıştır.

Biçer vd. (2016) Cumhuriyet Üniversitesi Sağlık Bilimleri Fakültesinde 1380 öğrenci üzerinde uyguladıkları çalışmalarında, öğrencilerin finansal okuryazarlık seviyelerini tutum, ilgi, harcama ve algı olmak üzere dört boyutta incelemiştir. Cinsiyet değişkeni açısından bakıldığında araştırmada dört boyutta da herhangi bir farklılık tespit edilememiştir. Finansal eğitim durumu değişkenine göre yapılan analizde ise finansal eğitim almayan öğrencilere göre finansal eğitim alan öğrencilerin algı boyutunda finansal okuryazarlık algılarının daha yüksek olduğu ortaya çıkmıştır.

Tosun (2016), lise öğrencilerinin finansal okuryazarlık konusunda sahip oldukları teorik bilgileri incelenmek istenmiş ve Trabzon Ortahisar ilçesinde yer alan öğrenciler üzerinde bir anket çalışması yapmıştır. Çalışmanın sonucunda Tosun, öğrencilerin finansal gelişmelere olan ilgilerinin düşük olduğunu ve temel terimler hakkında yeterli bilgiye sahip olmadıklarını tespit etmiştir. Ayrıca öğrencilerin finansal davranış ve tutumlar sergilediklerini ancak finansal bilgi düzeylerinin tutum ve davranışları üzerinde etkisinin az olduğunu da ifade etmiştir.

Baysa ve Karaca (2016), finansal okuryazarlık ve banka müşteri segmentasyonları üzerinde Tokat ilinde bir araştırmayı ele almışlardır. Çalışmada banka segment müşterilerinin finansal okuryazarlık düzeyinin düşük olduğu tespit edilmiştir. Yapılan araştırma sonucunda elde edilen bulgulara dayanarak, banka segment müşterilerinin finansal okuryazarlık seviyelerinin geliştirilmesine ilişkin önerilerde bulunulmuştur.

Çömlekçi (2017), katılım bankalarının müşterilerinin İslami finansal okuryazarlık düzeylerini ortaya koymak amacıyla bir çalışma ele almıştır. Bununla birlikte demografik faktörlere göre İslami finansal okuryazarlık seviyesinin farklllık gösterip göstermediğinin belirlenmesi çalışmanın bir diğer amacı olarak yer almıştır. Çalışmanın sonucunda katılım bankaları 
müşterilerinin İslami finansal bilgi düzeylerinin ve İslami finansal okuryazarlık düzeylerinin düşük olduğu tespit edilmiştir. Ayrıca İslami finansal okuryazarlık bilgi düzeyinin cinsiyet, yaş, eğitim, meslek grubu ve gelir düzeyine göre anlamlı bir farklılık gösterdiği sonuçlarına ulaşılmıştır.

Dağdelen (2017), Aydın ili ve ilçelerinde serbest muhasebeci mali müşavirlerin finansal okuryazarlık düzeylerini ölçülmeyi amaçlamıştır. Finansal okuryazarlık düzeyinin, serbest muhasebeci mali müşavirlerin yaş, cinsiyet ve eğitim durumuna göre tespit edilmesi hedeflenmiştir. Araştırma sonucunda, serbest muhasebeci mali müşavirlerin finansal okuryazarlık düzeyinin yüksek olduğu tespit edilmiştir. Araştırmanın sonucuna göre serbest muhasebeci mali müşavirlerin arasında eğitim ve yaş durumunun finansal okuryazarlık düzeyi üzerinde etkili olduğu ancak cinsiyet durumunun finansal okuryazarlık düzeyi üzerinde bir etkiye sahip olmadığı sonucuna ulaşılmıştır.

Yılmaz ve Tuncay (2017), Dicle Üniversitesi İktisadi ve İdari Bilimler Fakültesi öğrencilerinin finansal okuryazarlık seviyesini ölçmek, davranış tutumlarının finansal okuryazarlık ile ilişkisini ortaya koymak amacıyla ele aldıkları çalışmalarında anket yöntemini kullanmışlar ve araştırmanın sonucunda öğrencilerin finansal okuryazarlık düzeylerinin orta seviyede olduğunu, öğrencilerin temel bankacılık hususunda daha çok bilgiye sahip olmalarına rağmen tasarruf ve yatırım konusunun öğrenciler tarafından en az bilgi sahibi olunan konular olduğunu ortaya koymuşlardır.

Contuk (2018) tarafından yapılan çalışmada Muğla Sıtkı Koçman Üniversitesi İktisadi ve İdari Bilimler Fakültesi İşletme Bölümünde eğitim gören öğrencilerin finansal okuryazarlık durumunu etkileyen temel faktörler incelenmiştir. Yapılan çalışmanın analizinde Ki-Kare Test İstatistiği kullanılmıştır. Çalışmanın sonuçlarına göre öğrencilerin büyük bir kısmının temel düzeyde finans bilgisine sahip olduğu ancak ileri seviyede finans bilgilerinin yetersiz olduğu sonucuna ulaşılmıştır. Bununla birlikte, öğrencilerin genel olarak finans bilgilerinin eğitim düzeyi ve demografik özelliklerinden etkilendiği vurgulanmıştır.

Çil Koçyiğit vd. (2018) tarafından yapılan çalışmada, finansal eğitim verilen Ankara Hacı Bayram Veli Üniversitesi İktisadi ve İdari Bilimler Fakültesi bünyesinde yer alan Sağlık Yönetimi Bölümü lisans öğrencileri ile İşletme Bölümü lisans öğrencilerinin finansal okuryazarlık düzeyleri belirlenmiştir. Araştırma ile katılımcıların bölüm ve sınıflar bazında finansal okuryazarlık düzeylerinin farklı olduğu ayrıca da katılımcıların finansal okuryazarlık düzeylerinin herhangi bir işte çalışma durumları ve kredi kartına sahip olmalarına göre de anlamlı farklılıklar gösterdiği sonucuna ulaşılmıştır.

Uluslararası literatüre bakıldığında finansal okuryazarlık alanında yapılan çalışmalarda ulusal literatüre benzer bir yaklaşım görülmektedir. Çalışmaların büyük çoğunluğu ele alınan örneklem grubunun ilk olarak finansal okuryazarlık düzeyini ortaya koymayı amaçlamıştır.

Chen ve Volpe (2002), ABD'de 924 üniversite öğrencisi örnekleminde öğrencilerin karakteri ve finansal okuryazarlık düzeyleri ile öğrencilerin düşünce ve kararları arasındaki ilişkiyi analiz etmek amacıyla bir çalışma ele almıştır. Finansal okuryazarlık bilgi düzeyinin ölçüldüğü ankette bulunan soruların tümüne doğru cevap veren katılımcların oranı \%53 olarak tespit edilmiştir. Çalışmanın sonucunda cinsiyet olarak kadınların, eğitim düzeyi anlamında yeni girişli öğrencilerin, çalışma tecrübesi anlamında iş deneyimi az olanların ve yaş olarak bakıldığında otuz yaş altında bulunan kişilerin finansal okuryazarlık düzeylerinin düşük olduğu tespit edilmiştir.

Lusardi (2008) ABD’de bazı etnik gruplar üzerinde yaptığı çalışmasına göre cinsiyet bakımından kadınların ve uyruk bakımından Afrikalıların Amerikalılara göre eğitim 
seviyesinin daha düşük olduğunu ve bu kişilerin finansal okuryazarlık seviyelerinin de düşük olduğunu, hatta finansal cehaletin toplumun geneline yayıldığı tespit etmiştir. Lusardi (2009), tüketiciler üzerinde yaptığı araştırmasının sonucunda, tüketicilerin basit finansal hesaplamaları dahi yapamadıkları ve finansal piyasalarla ilgili kavramları anlamadıkları sonucuna varmıştır. Benzer şekilde Lusardi (2009a) 55 yaş ve üzeri tüketiciler üzerinde yaptı̆̆ 1 çalışmasında, bu kişilerin temel finans bilgilerinin olmadığı sonucuna varmıştır. Lusardi: (2009b) finansal okuryazarlık düzeyinin tespiti yanında $\mathrm{ABD}^{\prime}$ li çalışanlar üzerinde yapmış olduğu araştırmaya göre, çalışan birçok kişinin emekliliğe girerken çok az miktarda tasarrufunun bulunduğu ve çalışanların büyük bir bölümünün de emeklilik planı yapmadığı sonucuna varmıştır.

Tamaskova vd. (2011) yapmış oldukları çalışmada finansal okuryazarlığın mevcut sorunlarını uluslararası düzeyde ele almışlardır. Çalışmada mevcut nüfusun bilgi düzeyinin artırılmasının finansal okuryazarlık düzeylerinin yükselmesine yardımcı olacağı savunulmuştur. Finansal ürün ve hizmetlerin piyasada aktif yer alması için bireylerin finansal okuryazarlık bilgi ve beceri düzeylerini arttırmaları gerektiği vurgulanmıştır. Bu sayede bireylerin hem kendi bütçelerini yönetebileceği hem de fiyat ve para konularındaki sorunları rahatlıkla çözebileceği belirtilmiştir.

Chlouba vd. (2011) Bilgi Yönetimi ve Araştırma Fakültesi öğrencilerinin finansal okuryazarlık eğitimine olan ihtiyaçlarının belirlenmesine yönelik anket uygulaması yapmıştır. Çalışmaya göre, öğrencilerin finansal konularla ilgili kararlar alırken finansal okuryazarlık temel bilgisine sahip olmadıkları görülmüştür.

Tamaskova vd. (2013) ele aldıkları çalışmada 1000 Rus vatandaşına 2008 ve 2009 yıllarında uyguladıkları anket sonucunda hane halkı özellikleri kontrol edildikten sonra finansal kriz sürecinde harcanmamış gelir düzeyinin finansal okuryazarlık ile ilişkisinin yüksek olduğu sonucuna ulaşmıştır. Başka bir deyişle beklenmedik makroekonomik ve gelir şokuyla karşı karşıya kalındığında finansal okuryazarlık bireylere büyük düzeyde yardımcı olmaktadır.

Disney ve Gathergood (2013) tüketici kredisi ile finansal okuryazarlık arasındaki ilişkiyi Birleşik Krallık'ta yapmış oldukları bir çalışmada incelemişlerdir. Çalışmanın sonuçlarına göre tüketici kredisi kullanan bireylerin finansal okuryazarlık seviyesinin düşük olduğu ve düşük finansal okuryazarlığa sahip bireylerin ise finansal konularda güven eksikliği hissettiği vurgulanmıştır.

Gaisina ve Kaidarova (2017) temel amacı gelişmekte olan ülkelerin ekonomilerinde finansal okuryazarlık düzeylerinin araştırılması olan çalışmalarında finansal kararlar dâhil olmak üzere tasarruf ile ilgili sosyo-ekonomik belirleyiciler olarak tasarruf oranları, gelir düzeyi, aile büyüklüğü ve istihdam durumu gibi faktörleri dikkate almıştır. Kazakistan Pavlodar bölgesinde yapılan bu araştırma 2014 ilkbaharında gerçekleştirilmiştir. Toplam 405 aile çalışmaya katılmıştır. Analiz sonuçlarına göre finansal okuryazarlık düzeyi tasarruf oranlarını olumlu bir şekilde etkilemektedir. Kırsal kesimde devlet destekli finansal eğitim programlarının kullanılmasının insanlarda önemli ölçüde finansal okuryazarlık gelişimi sağlayacağı belirtilmiştir. Aynı zamanda, kırsal alanlarda yaşayan insanları uygun mali ürünler hakkında bilgi edinmek ve seçmek hususunda motive edecek ve bu alandaki faaliyetleri yoğunlaştıracak yetkililere ihtiyaç olduğu ortaya konulmuştur.

\section{VERI SETI VE YÖNTEM}

$\mathrm{Bu}$ çalışma Kırıkkale Üniversitesi akademik ve idari personelinin finansal okuryazarlık düzeyini tespit etmek ve finansal okuryazarlık düzeyi ile tasarruf eğilimleri arasındaki ilişkiyi ortaya koymayı amaçlamaktadır. Toplam 1216 akademik ve 879 idari personelin çalışmakta olduğu Kırıkkale üniversitesinden 438 kişiyle bire bir görüşmek suretiyle anket uygulanmıştır. Kullanılan anket Lusardi (2008) tarafından hazırlanmış ve ölçeklendirilmiş ankettir. 
Katılımcları anket ile ilgili soruları gerekli açıklamalar yapılmıştır. Analizlerde değişkenler arasındaki ilişki Ki-Kare testi ile sınanmıştır. Finansal okuryazarlık düzeyi ile demografik özellikler arasındaki ilişkiye yönelik hipotezler için parametrik test yöntemleri arasında yer alan t testi ve Anova testi uygulanmıştır. Anova testi sonucunda gruplar arasında fark çıkması durumunda bu farkın hangi gruptan kaynaklandığını bulmak için post hoc testleri arasında yer alan tukey testi uygulanmıştır. İstatistiksel yorumlamalar yapılırken, ankette yer olan sorulara verilen yanıtların tümü için frekans analizleri yapılarak yüzdelik dilimlerle ifade edilmiştir. Araştırmanın hipotezleri aşağıda belirtildiği gibidir:

H1: Temel düzey ve ileri düzey finansal okuryazarlık düzeyleri cinsiyette göre istatistiksel olarak farklılık göstermektedir.

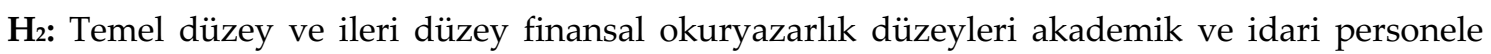
göre istatistiksel olarak farklılık göstermektedir.

$\mathbf{H}_{3}$ : Temel düzey ve ileri düzey finansal okuryazarlık düzeyleri eğitim durumunu göre istatistiksel olarak farklılık göstermektedir.

$\mathbf{H}_{4}$ : Gelirin bir kısmını tasarruf etme durumu temel düzey ve ileri düzey finansal okuryazarlık düzeyine göre istatistiksel olarak farklılık göstermektedir.

H5: Tasarruf yapma oranı temel düzey ve ileri düzey finansal okuryazarlık düzeyine göre istatistiksel olarak farklılık göstermektedir.

\section{ARAŞTIRMA BULGULARI}

Araştırmada yer alan bireylere ait demografik özellikler aşağıda gösterilen Tablo 1- 6 arasında özetlenmiştir.

Tablo 1. Araştırmaya Katılanların Cinsiyet Grubuna İlişkin Frekans ve Yüzde Dağılımı

\begin{tabular}{|l|c|c|}
\hline \multicolumn{1}{|c|}{ Cinsiyet } & Frekans & Yüzde (\%) \\
\hline Erkek & 281 & 64,2 \\
\hline Kadın & 157 & 35,8 \\
\hline Toplam & 438 & 100,0 \\
\hline
\end{tabular}

Anketin uygulandığ1 örneklem grubunda katılan kişilerin \%64,2'si yani 281 kişi erkek, \%35,8'si yani 157 kişi kadınlardan oluşmaktadır. Erkek ve kadın dağılımı arasındaki farklara baktığımızda araştırma katılımcıları arasında cinsiyet açısından çok büyük fark olduğu gözlemlenmektedir.

Tablo 2. Araştırmaya Katılanların Yaş Grubuna İlişkin Frekans ve Yüzde Dağılımı

\begin{tabular}{|l|c|c|}
\hline \multicolumn{1}{|c|}{ Yaş Grubu } & Frekans & Yüzde (\%) \\
\hline $20-30$ & 120 & 27,4 \\
\hline $30-40$ & 157 & 35,8 \\
\hline $40-50$ & 101 & 23,1 \\
\hline $50-60$ & 60 & 13,7 \\
\hline Toplam & 438 & 100,0 \\
\hline
\end{tabular}

Katılımcıların yaş gruplarına göre dağılımları yukarıdaki tabloda yer almaktadır. Tabloya bakıldığında 30-40 yaş aralığında yer alan kişilerin en fazla ağırlığa sahip olduğu (\%35,8 ile 157 kişi), 50-60 yaş grubunda yer alan bireylerin (\%13,7 ile 60 kişi) katılımcıların en küçük kısmını oluşturduğu görülmektedir. 
Tablo 3. Araştırmaya Katılan Akademik Ve İdari Personele İlişkin Frekans Ve Yüzdeler Dağılımı

\begin{tabular}{|l|c|c|}
\hline Akademik veya İdari personel & Frekans & Yüzde (\%) \\
\hline Akademik personel & 279 & 63,7 \\
\hline İdari personel & 159 & 36,3 \\
\hline Toplam & 438 & 100,0 \\
\hline
\end{tabular}

Yukarıdaki tabloya bakıldığında araştırmaya katılanları \%63,7'sinin yani 279 kişinin akademik personel olduğu, 36,3'ünün yani 159 kişi ise idari personel olduğu görülmektedir.

Tablo 4. Araştırmaya Katılanların Unvanına İlişkin Frekans ve Yüzdeler Dağılımı

\begin{tabular}{|l|c|c|}
\hline Unvan & Frekans & Yüzde (\%) \\
\hline Araştırma Görevlisi & 118 & 26,6 \\
\hline Öğretim Görevlisi & 30 & 6,8 \\
\hline Dr. Öğr. Üyesi & 68 & 15,5 \\
\hline Doç. Dr & 34 & 7,8 \\
\hline Prof. Dr & 32 & 7,3 \\
\hline Toplam & 282 & 64,4 \\
\hline Diğgr (Uzman ve İdari Personel) & 156 & 35,6 \\
\hline Toplam & 438 & 100,0 \\
\hline
\end{tabular}

Araştırmaya katılanların \%26,9'ünün yani 118 kişinin Araştırma Görevlisi olduğu ve 6,8'sının yani 30 kişinin Öğretim Görevlisi olduğu, \%15,5'inin 68 kişinin Doktor Öğretim Üyesi olduğu, \%7,8'sinin 34 kişinin Doçent olduğu, \%7,3'ünün 32 kişinin Profesör olduğu görülmektedir. Ayrıca yüzde \%35,6'sı diğer uzman ve idari personelden oluşturmaktadır. Tabloya bakıldığında örneklem içindeki en büyük payın $\% 26,9$ oranı ile araştırma görevlilerinde; en düşük payın ise $\% 6,8$ ile öğretim görevlilerinde olduğu görülmektedir.

Tablo 5. Araştırmaya Katılanların Eğitim Düzeyine Ait Frekans ve Yüzdeler Dağılımı

\begin{tabular}{|l|c|c|}
\hline Eğitim Düzeyi & Frekans & Yüzde (\%) \\
\hline Lise & 38 & 8,7 \\
\hline Üniversite & 108 & 24,7 \\
\hline Yüksek Lisans & 103 & 23,5 \\
\hline Doktora & 178 & 40,6 \\
\hline Diğer & 11 & 2,5 \\
\hline Toplam & 438 & 100,0 \\
\hline
\end{tabular}

Katılımcıların eğitim düzeyini gösteren sayılar ile yüzdelik dilimlere bakıldığında, en büyük oranda $(\% 40,6)$ katılımcının 178 kişi ile doktora mezunları olduğu, lise ve diğer eğitim düzeyinde yer olan katılımcıların 38 kişinin lise mezunu ve 11 kişinin diğer ilkokul veya ortaokul mezunu olduğu görülmektedir.

Tablo 6. Katılımcıların Gelir Durumunun Frekans ve Yüzde Dağılımı

\begin{tabular}{|l|c|c|}
\hline Gelir & Frekans & Yüzde (\%) \\
\hline $2500-3500$ & 110 & 25,1 \\
\hline $3500-4500$ & 54 & 12,3 \\
\hline $4500-5500$ & 162 & 37,0 \\
\hline $5500-6500$ & 58 & 13,2 \\
\hline 6500 ve üstü & 54 & 12,3 \\
\hline Toplam & 438 & 100,0 \\
\hline
\end{tabular}


Tablo 6.'ya bakıldığında katılımcıların en yüksek geliri sahibi olanların toplam katılımcıların $\% 12,3$ 'ü olduğu yani 54 kişinin gelirinin 6500 TL ve üstü olduğu görülmektedir. Gelir düzeyi bakımından en çok katılımın \%37,0 oranı ile geliri 4500-5500 TL aralığında olan katılımcılar tarafından sağlandığı, geliri 2500-3500 TL aralığında olan kişilerin katılımcıların \%25,1'ini oluşturduğu gözlemlenmektedir.

Tablo 7. Katılımcıların Ekonomik ve Finansal Gelişmeleri Hangi Sıklıkla Takip Etmesi Gerektiğine İlişkin Frekans ve Yüzde Dağılımları

\begin{tabular}{|l|c|c|}
\hline $\begin{array}{l}\text { Ekonomik ve Finansal Gelişmeleri Hangi Sıklıkla Takip } \\
\text { Ediyorsunuz? }\end{array}$ & Frekans & Yüzde (\%) \\
\hline Hiç & 55 & 12,6 \\
\hline Ayda bir kez & 112 & 25,6 \\
\hline Haftada birkaç kez & 161 & 36,8 \\
\hline Her gün & 108 & 24,7 \\
\hline Diğer & 2 &, 5 \\
\hline Toplam & 438 & 100,0 \\
\hline
\end{tabular}

Tablo 7'de ekonomik gelişmeler ile finans odaklı gelişmeleri takip etme açısından katılımcıların \%36,8'inin 161 kişinin haftada birkaç kez finansal gelişmeleri takip ettikleri, \%25,6'sının 112 kişinin ise finansal gelişmeleri ayda bir kez takip ettikleri görülmüştür. Diğer taraftan $\% 24,8^{\prime}$ nin 108 kişinin finansal gelişmeleri her gün takip ettikleri belirlenmiştir. En düşük oran olarak \%12,6'sının 55 kişinin hiç takip etmedikleri görülmüştür. Bu sonuçlar açısından bakıldığında haftada birkaç kez, ayda birkaç kez ve her gün finansal gelişmeleri takip etme oranlarının birbirine yakın olduğu görülebilir. Bu durum, finansal gelişmeleri takip etme açısından ilgili bir hedef kitleye sahip olunduğunun göstergesidir.

Tablo 8. Gelirinizin Bir Kısmını Tasarruf Eder Misiniz Sorusuna İlişkin Frekans ve Yüzde Dağılımları

\begin{tabular}{|l|c|c|}
\hline Gelirinizin Bir Kısmını Tasarruf Eder misiniz? & Frekans & Yüzde (\%) \\
\hline Evet & 320 & 73,1 \\
\hline Hayır & 118 & 26,9 \\
\hline Toplam & 438 & 100,0 \\
\hline
\end{tabular}

Tablo 8'de katılımcıların \%73,1'inin yani 320 kişinin gelirlerinin bir kısmını tasarruf ettikleri görülmektedir. Diğer taraftan katılımcıların \%26,9'unun yani 118 kişinin ise gelirlerinin bir kısmını tasarruf etmeyi tercih etmedikleri belirtilmiştir. Bu sonuçlar açısından \%73,1 gibi büyük bir çoğunluğun gelirlerinin bir kısmını tasarruf etmeyi tercih ettiğini beyan etmesi toplumsal özellikler açısından da beklenen bir sonuçtur. Sonuç olarak bireyler-toplum için yastık altı bile olsa tasarrufun önemsendiği beklenen sonucu elde edilmiştir. Ayrıca bu oransal dağılım sadece akademik ve idari personeli kapsayan bir örneklem olması nedeniyle eğitim seviyesi ile tasarruf eğilimi arasında anlamlı bir ilişki bulunduğuna dair bir ön bulgu olarak nitelendirilebilir.

Tablo 9. Eğer Tasarruf Ediyorsanız Gelirinizin Ne Kadarını Tasarruf Edersiniz Sorusuna İlişkin Frekans ve Yüzde Dağılımları

\begin{tabular}{|l|c|c|}
\hline Eğer Tasarruf Ediyorsanız Gelirinizin Ne Kadarını Tasarruf Edersiniz? & Frekans & Yüzde (\%) \\
\hline \%10- ve altı & 159 & 36,3 \\
\hline \%10-20 & 135 & 30,8 \\
\hline \%20'den fazla & 85 & 19,4 \\
\hline Diğer & 59 & 13,5 \\
\hline Toplam & 438 & 100,0 \\
\hline
\end{tabular}


Yukarıdaki tabloya bakıldığında eğer tasarruf ediyorsanız gelirinizin ne kadarını tasarruf edersiniz? sorusuna katılımcıların \%36,3'ünün yani 159 kişinin $\% 10$ ve altını tasarruf ettiklerini, $\% 30,8^{\prime}$ inin yani 135 kişinin \%10-20 aralığında tasarruf ettiklerini ve \%19,4'ünün yani 85 kişinin \%20 den fazla tasarruf ettiklerini beyan ettikleri görülmüştür. $\mathrm{Bu}$ açıdan tasarrufun önemsendiği bir örneklemle çalışmanın yürütüldüğü görülmektedir.

Tablo 10. Tasarruflarınızı Nasıl Muhafaza Edersiniz Sonucuna İlişkin Frekans ve Yüzdeler Dağılımı

\begin{tabular}{|l|c|c|}
\hline Tasarruflarınızı Nasıl Muhafaza Dersiniz? & Frekans & Yüzde(\%) \\
\hline Bankada Muhafaza etmem & 199 & 45,4 \\
\hline Bankada Muhafaza ederim & 181 & 41,3 \\
\hline Diğer & 58 & 13,2 \\
\hline Toplam & 438 & 100,0 \\
\hline Özel Emeklilik Yapmam & 336 & 76,7 \\
\hline Özel emeklilik Yaparım & 44 & 10,0 \\
\hline Diğer & 58 & 13,2 \\
\hline Toplam & 438 & 100,0 \\
\hline Eve Yatırım Yapmam & 339 & 77,4 \\
\hline Eve Yatırım Yaparım & 41 & 9,4 \\
\hline Diğer & 58 & 13,2 \\
\hline Toplam & 438 & 100,0 \\
\hline $\begin{array}{l}\text { Çeşitli finansal yatırım araçlara (altın, döviz, hisse senedi, } \\
\text { tahvil) yatırım yapmam }\end{array}$ & 219 & 50,0 \\
\hline $\begin{array}{l}\text { Çeşitli finansal yatırım araçlara (altın, döviz, hisse senedi, } \\
\text { tahvil) yatırım yaparım }\end{array}$ & 161 & 36,8 \\
\hline Diğer & & 13,2 \\
\hline Toplam & 438 & 100,0 \\
\hline Arkadaşlarıma borç vermeyeceğim & 363 & 82,9 \\
\hline Arkadaşlarıma borç vererek yatırım yaparım & 17 & 3,9 \\
\hline Diğer & 58 & 13,2 \\
\hline Toplam & 438 & 100,0 \\
\hline
\end{tabular}

Tablo 10 'da tasarruflarınızı nasıl muhafaza edersiniz sorusuna katılımcıların $\% 45,4^{\prime}$ ünün yani 199 kişinin bankada muhafaza etmediğini \%41,3'nün yani 181 kişinin ise tasarruflarını bankada muhafaza ettiklerini belirttikleri görülmüştür. Bu sonuçlar sıklıkla dile getirilen ve ekonomiye kazandırılması açısından çeşitli teşvikler sunulan yastık altı kültürünün önemli bir düzeyde olduğunun göstergesi niteliğindedir. Bununla birlikte bankada muhafaza etmeyenler arasında çeşitli gayrimenkul birikimlerinin de önemsenmesi ve dikkate alınması gerekmektedir. Tasarruflarınızı nasıl muhafaza edersiniz sorusuna katılımcıların büyük bir kısmı \%76,7'si yani 336 kişi özel emekliliğe yatırım yapmayacaklarına ifade ederek cevap vermiştir. Aynı soruya yine katılımcıların büyük bir kısmı \%77,4'ü yani 339 kişi eve yatırım yapmam, \%50,0'si yani 219 kişi çeşitli finansal yatırım araçlarına (altın, döviz, hisse senedi, tahvil gibi) yatırım yapmam, \%82,9'ü yani 363 kişinin arkadaşlarıma borç vermem şeklinde cevap vermiştir.

Temel Düzey ve İleri Düzey Okuryazarlığın Cinsiyet, Akademik ve İdari personel ile Eğitim Düzeyi Açısından Farklılaşmasına İlişkin Varyans Analizleri ve T testi Analiz Bulguları

Cinsiyetin temel düzey ve ileri düzey finansal okuryazarlık üzerinde anlamlı bir farklılık yaratıp yaratmadığını ölçmek amacıyla aşağıdaki hipotez kurulmuş ve bağımsız örneklem $t$ testi uygulanmıştır. 
Hı: Temel düzey ve ileri düzey finansal okuryazarlık düzeyleri cinsiyette göre istatistiksel olarak farklılık göstermektedir.

$H_{0}$ : Temel düzey ve ileri düzey finansal okuryazarlık düzeyleri cinsiyette göre istatistiksel olarak farklılık göstermemektedir.

Tablo 11. Temel Düzey ve İleri Düzey Finansal Okuryazarlık Düzeyinin Cinsiyete göre Farklılığının Tespitine Yönelik t Testi Sonuçları

\begin{tabular}{|c|c|c|c|c|c|c|}
\hline & Cinsiyet & $\mathbf{N}$ & Mean & $\begin{array}{c}\text { Std. } \\
\text { Sapma }\end{array}$ & $\mathrm{T}$ & $\mathbf{p}$ \\
\hline \multirow{2}{*}{$\begin{array}{l}\text { İleri Düzey Finansal } \\
\text { Okuryazarlık }\end{array}$} & Erkek & 281 & 5,2349 & 2,92068 & \multirow{2}{*}{1,740} & \multirow{2}{*}{,001 } \\
\hline & Kadın & 157 & 4,2739 & 2,60820 & & \\
\hline \multirow{2}{*}{$\begin{array}{l}\text { Temel Düzey Finansal } \\
\text { Okuryazarlık }\end{array}$} & Erkek & 278 & 3,3094 & 1,54756 & \multirow{2}{*}{,007 } & \multirow{2}{*}{, 580} \\
\hline & Kadın & 160 & 3,3949 & 1,54736 & & \\
\hline
\end{tabular}

Tablo 11'de özetlenen sonuçlara göre temel düzey finansal okuryazarlık açısından p değeri 0.580 olarak çıktığı için \%95 anlamlılık düzeyinde cinsiyet açısından temel düzey okuryazarlık düzeyinde anlamlı bir farklılık görülmemiştir. İleri düzey okuryazarlık ile cinsiyet açısından $p$ değerleri 0.001 çıktığından dolayı \%99 önem seviyesinde anlamlı çıkmıştır. Yani cinsiyet açısından ileri düzey finansal okuryazarlık anlamlı bir farklılık arz etmektedir.

Akademik ve idari personel olma durumunun temel düzey ve ileri düzey finansal okuryazarlık üzerinde anlamlı bir farklılık yaratıp yaratmadığını ölçmek amacıyla aşağıdaki hipotez kurulmuş ve bağımsız örneklem $t$ testi uygulanmıştır.

$\mathbf{H}_{2}$ : Temel düzey ve ileri düzey finansal okuryazarlık düzeyleri akademik ve idari personel olma durumuna göre istatistiksel olarak farkl1lık göstermektedir.

$H_{0}$ : Temel düzey ve ileri düzey finansal okuryazarlık düzeyleri akademik ve idari personel olma durumuna göre istatistiksel olarak farklılık göstermemektedir.

Tablo 12. Temel Düzey ve İleri Düzey Finansal Okuryazarlık Düzeyinin Akademik ve İdari Personel Açısından Farklılaşma Derecesini Tespite Yönelik Olarak Bağımsız Örnekler TTesti Sonuçları

\begin{tabular}{|c|c|c|c|c|c|c|}
\hline & $\begin{array}{l}\text { Akademik ve } \\
\text { İdari Personel }\end{array}$ & $\mathbf{N}$ & Mean & $\begin{array}{c}\text { Std. } \\
\text { Sapma }\end{array}$ & $\mathbf{F}$ & Sig \\
\hline \multirow{2}{*}{$\begin{array}{l}\text { Temel düzey finansal } \\
\text { okuryazarlık }\end{array}$} & Akademik personel & 277 & 3,5415 & 1,53789 & \multirow[t]{2}{*}{ 199 } & \multirow[t]{2}{*}{,000 } \\
\hline & İdari personel & 161 & 2,9873 & 1,50154 & & \\
\hline \multirow{2}{*}{$\begin{array}{l}\text { Illeri düzey finansal } \\
\text { okuryazarlık }\end{array}$} & Akademik personel & 279 & 5,0430 & 2,97803 & \multirow[t]{2}{*}{4,226} & \multirow[t]{2}{*}{ 138 } \\
\hline & İdari personel & 159 & 4,6226 & 2,58936 & & \\
\hline
\end{tabular}

Tablo 12'de özetlenen sonuçlara göre ileri düzey finansal okuryazarlık açısından akademik ve idari personelin farklılaşma derecesi \%95 önem seviyesinde, p değeri 0,138 olarak bulunmuştur. $\mathrm{Bu}$ durum ileri düzey finansal okuryazarlık düzeyinde gruplar arasında anlamlı bir fark olmadığını göstermektedir. Temel düzey finansal okuryazarlık açısından ise p değeri 0.001 ile \%99 önem düzeyinde anlamlı bir farklılık göstermektedir. Bu durumun temel sebebinin daha yüksek ortalama değerlerine sahip olan akademik personelden kaynaklandığı söylenebilir. Yani akademik personel temel düzeyde finansal okuryazarlık eğilimleri açısından idari personele oranla daha fazla bilinçlidir.

Eğitim durumunun temel düzey ve ileri düzey finansal okuryazarlık üzerinde anlamlı bir farklılık yaratıp yaratmadığını ölçmek amacıyla aşağıdaki hipotez kurulmuş ve Tek Yönlü Anova testi uygulanmıştır. 
$\mathbf{H}_{3}$ : Temel düzey ve ileri düzey finansal okuryazarlık düzeyleri eğitim durumuna göre istatistiksel olarak farklılık göstermektedir.

$H_{0}$ : Temel düzey ve ileri düzey finansal okuryazarlık düzeyleri eğitim durumuna göre istatistiksel olarak farklılık göstermemektedir.

Tablo 13. Temel Düzey ve İleri Düzey Finansal Okuryazarlık Düzeyinin Eğitim Durumu Açısından Farklılaşma Derecesinin Tespitine Yönelik One-Way Anova Testi Sonuçları

\begin{tabular}{|c|c|c|c|c|c|c|}
\hline & & $\mathbf{N}$ & Mean & Std. Sapma & $\mathbf{F}$ & Sig. \\
\hline \multirow{6}{*}{$\begin{array}{l}\text { Temel Düzey Finansal } \\
\text { Okuryazarlık }\end{array}$} & Lise & 38 & 2,6316 & 1,58406 & \multirow{6}{*}{3,805} & \multirow{6}{*}{0,005} \\
\hline & Üniversite & 107 & 3,1776 & 1,47183 & & \\
\hline & Yüksek Lisans & 101 & 3,5446 & 1,53964 & & \\
\hline & Doktora & 178 & 3,5112 & 1,52656 & & \\
\hline & Diğer & 11 & 2,7273 & 1,73729 & & \\
\hline & Total & 435 & 3,3402 & 1,54625 & & \\
\hline \multirow{6}{*}{$\begin{array}{l}\text { İleri Düzey Finansal } \\
\text { Okuryazarlık }\end{array}$} & Lise & 38 & 3,6053 & 2,28437 & \multirow{6}{*}{3,342} & \multirow{6}{*}{0,010} \\
\hline & Üniversite & 108 & 5,2963 & 2,55138 & & \\
\hline & Yüksek Lisans & 103 & 4,6796 & 2,91787 & & \\
\hline & \begin{tabular}{|l|} 
Doktora \\
\end{tabular} & 178 & 5,1067 & 2,99054 & & \\
\hline & Diğer & 11 & 3,8182 & 3,09251 & & \\
\hline & Total & 438 & 4,8904 & 2,84727 & & \\
\hline
\end{tabular}

Tablo 13'te görüldügü üzere yapılan analiz sonuçlarına göre, finansal okuryazarlık düzeyinin alt boyutlarından olan temel finansal okuryazarlık düzeyinin eğitim durumuna göre istatistiksel olarak anlamlı bir farklılık gösterdiği $(p<0,05)$ tespit edilmiştir. Eğitim durumu açısından temel finansal okuryazarlık düzeyi ortalamaları incelendiğinde, en düşük finansal okuryazarlık ortalamasının lise $(2,63)$ eğitimine sahip olanların; en yüksek ise yüksek lisans $(3,54)$ ve doktora eğitimine $(3,51)$ sahip olanların olduğu gözlemlenmiştir. İleri düzey finansal okuryazarlığın da olasılık değeri 0.010 olduğundan \%95 önem düzeyinde anlamlı bir farklılık sergilediği görülmüştür. Bu farkın hangi gruptan kaynaklandığını test etmek için post hoc analizi kullanılmıştır. Sonuçları Tablo 14'te ayrıntılı şekilde gösterilmiştir.

Tablo 14. Temel Düzey ve İleri Düzey Finansal Okuryazarlık Düzeyinin Eğitim Durumuna Göre Farklılığının Tespitine Yönelik Post-Hoc Analizi

\begin{tabular}{|c|c|c|c|c|c|}
\hline \multicolumn{2}{|c|}{ Bağımlı değişken } & (I) Eğitim düzeyi & (J) Eğitim düzeyi & Ortalama Fark (I-J) & Sig. \\
\hline \multirow{13}{*}{$\begin{array}{l}\text { Temel Düzey } \\
\text { Finansal } \\
\text { Okuryazarlık }\end{array}$} & \multirow{13}{*}{ Tukey HSD } & \multirow{4}{*}{ Lise } & Üniversite &,- 54599 & 322 \\
\hline & & & Yüksek Lisans &,$- 91298^{*}$ & ,015 \\
\hline & & & Doktora &,$- 87966^{*}$ & ,012 \\
\hline & & & Diğer & 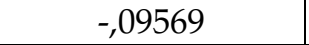 & 1,00 \\
\hline & & \multirow{4}{*}{ Üniversite } & Lise & ,54599 & 322 \\
\hline & & & Yüksek Lisans &,- 36698 & ,415 \\
\hline & & & Doktora &,- 33367 & 383 \\
\hline & & & Diğer & ,45030 & ,885 \\
\hline & & \multirow{4}{*}{ Yüksek Lisans } & Lise & -91298* & 015 \\
\hline & & & Üniversite & ,36698 & ,415 \\
\hline & & & Doktora & ,03332 & 1,00 \\
\hline & & & Diğer & ,81728 & 444 \\
\hline & & Doktora & Lise & ,87966* & 012 \\
\hline
\end{tabular}


M. Oktay - İ. E. Kandil Göker, 1 (1): 34-55

\begin{tabular}{|c|c|c|c|c|c|}
\hline & & & Üniversite & ,33367 & ,383 \\
\hline & & & Yüksek Lisans &,- 03332 & 1,000 \\
\hline & & & Diğer & ,78396 & 464 \\
\hline & & & Lise & 09569 & 1,00 \\
\hline & & Dił̌̆on & Üniversite &,- 45030 & 885 \\
\hline & & Diger & Yüksek Lisans &,- 81728 & 444 \\
\hline & & & Doktora &,- 78396 & 464 \\
\hline & & & Üniversite &,- 54599 & 059 \\
\hline & & & Yüksek Lisans &,$- 91298^{*}$ & ,002 \\
\hline & & Lise & Doktora &,$- 87966^{*}$ & ,001 \\
\hline & & & Diğer &,- 09569 & 855 \\
\hline & & & Lise & ,54599 & ,059 \\
\hline & & Üniversite & Yüksek Lisans &,- 36698 & 084 \\
\hline & & Universite & Doktora &,- 33367 & 075 \\
\hline & & & Diğer & 45030 & ,352 \\
\hline & & & Lise & ,91298* & ,002 \\
\hline & I SD & Yükcok I icanc & Üniversite & ,36698 & 084 \\
\hline & LSD & ruKseK Lisans & Doktora & ,03332 & 861 \\
\hline & & & Diğer & ,81728 & ,093 \\
\hline & & & Lise & $87966^{*}$ & 001 \\
\hline & & Doktora & Üniversite & ,33367 & 075 \\
\hline & & Doktora & Yüksek Lisans &,- 03332 & 861 \\
\hline & & & Diğer & ,78396 & 099 \\
\hline & & & Lise & ,09569 & 855 \\
\hline & & Diy̌or & Üniversite &,- 45030 & ,352 \\
\hline & & Diger & Yüksek Lisans &,- 81728 & ,093 \\
\hline & & & Doktora &,- 78396 & 099 \\
\hline & & & Üniversite & $-1,69103^{*}$ & ,014 \\
\hline & & J ico & Yüksek Lisans & $-1,07435$ & 263 \\
\hline & & Lise & Doktora & $-1,50148^{*}$ & 025 \\
\hline & & & Diğer &,- 21292 & 999 \\
\hline & & & Lise & $1,69103^{*}$ & 014 \\
\hline & & Ïnnivarcite & Yüksek Lisans & ,61668 & ,505 \\
\hline & & Universite & Doktora & , 18955 & ,982 \\
\hline & & & Diğer & 1,47811 & 461 \\
\hline & & & Lise & 1,07435 & ,263 \\
\hline |ìleri Düzoy & Tuker HSD & Yïkcok I icans & Üniversite &,- 61668 & ,505 \\
\hline $\begin{array}{l}\text { Finansal } \\
\text { Final Duzey }\end{array}$ & I Uкеу HSD & Y Yuksek Lisans & Doktora &,- 42713 & ,737 \\
\hline Finansal & & & Diğer & ,86143 & 871 \\
\hline & & & Lise & $1,50148^{*}$ & , 025 \\
\hline & & Doktom & Üniversite &,- 18955 & ,982 \\
\hline & & DOKtora & Yüksek Lisans & ,42713 & ,737 \\
\hline & & & Diğer & 1,28856 & ,581 \\
\hline & & & Lise & 21292 & ,999 \\
\hline & & Dišor & Üniversite & $-1,47811$ & 461 \\
\hline & & Diger & Yüksek Lisans &,- 86143 & 871 \\
\hline & & & Doktora & $-1,28856$ & ,581 \\
\hline
\end{tabular}


M. Oktay - İ. E. Kandil Göker, 1 (1): 34-55

\begin{tabular}{|c|c|c|c|c|}
\hline \multirow{20}{*}{ LSD } & \multirow{4}{*}{ Lise } & Üniversite & $-1,69103^{*}$ & ,002 \\
\hline & & Yüksek Lisans & $-1,07435^{*}$ & 045 \\
\hline & & Doktora & $-1,50148^{*}$ & ,003 \\
\hline & & Diğer &,- 21292 & 825 \\
\hline & \multirow{4}{*}{ Üniversite } & Lise & $1,69103^{*}$ &, 002 \\
\hline & & Yüksek Lisans & 61668 & ,38800 \\
\hline & & Doktora & 18955 & ,34362 \\
\hline & & Diğer & 1,47811 & ,89164 \\
\hline & \multirow{4}{*}{ Yüksek Lisans } & Lise & $1,07435^{*}$ & ,53471 \\
\hline & & Üniversite &,- 61668 & ,38800 \\
\hline & & Doktora &,- 42713 & ,34878 \\
\hline & & Diğer &, 86143 & ,89363 \\
\hline & \multirow{4}{*}{ Doktora } & Lise & $1,50148^{*}$ &, 50344 \\
\hline & & Üniversite &,- 18955 & ,34362 \\
\hline & & Yüksek Lisans & ,42713 & ,34878 \\
\hline & & Diğer & 1,28856 & ,87528 \\
\hline & \multirow{4}{*}{ Diğer } & Lise & ,21292 & ,96457 \\
\hline & & Üniversite & $-1,47811$ & ,89164 \\
\hline & & Yüksek Lisans &,- 86143 & 89363 \\
\hline & & Doktora & $-1,28856$ & ,87528 \\
\hline
\end{tabular}

Tukey testi ve LSD test sonuçlarına bakıldığında farkın lise ile yüksek lisans ve doktoradan kaynaklandığı görülmektedir. Yapılan LSD testi sonuçları yorumlanacak olursa; LSD testi sonuçlarında lisenin 0.02 gibi bir değerle yüksek lisanstan ve 0.01 gibi bir değerle de doktoradan \%99 önem düzeyinde farklılaştığı görülmektedir. Benzer bir şekilde yüksek lisansın liseden 0.02; doktoranın liseden 0,01 düzeyinde farklılaştığ görülmektedir. Yani temel düzey finansal okuryazarlık açısından yüksek lisans ve doktora eğitimi görmüş akademik ve idari personelin lise düzeyinde eğitim görmüş personele oranla daha fazla temel düzey finansal okuryazarlık becerilerine sahip oldukları görülmüştür. İleri düzey finansal okuryazarlık açısından bakıldığında LSD sonuçları yine lisenin üniversiteden 0.02, yüksek lisanstan 0.045 ve doktoradan 0.03 gibi bir değerlerde farklılaştığı görülmektedir. Yani üniversite yüksek lisans ve doktora eğitimi görmüş akademik ve idari personelin ileri düzey okuma yazma becerileri lise düzeyinde eğitim görmüş akademik ve idari personelden daha fazla olduğu tespit edilmiştir.

Bireylerin temel düzey ve ileri düzey finansal okuryazarlıkları ile gelirin bir kısmını tasarruf etme durumları arasındaki ilişkinin Ki Kare Analizi ile incelemek amacıyla $\mathrm{H}_{0}$ : Gelirin bir kısmını tasarruf etme durumu ileri düzey finansal okuryazarlık ile bağlantılı değildir. $\mathrm{H}_{2}$ : Gelirin bir kısmını tasarruf etme durumu ileri düzey finansal okuryazarlık ile bağlantılıdır. Hipotezler kurulmuştur. Elde edilen bulgular Tablo 15'te özetlenmiştir.

Tablo 15. Temel Düzey ve İleri Düzey Finansal Okuryazarlık İle Gelirin Bir Kısmını Tasarruf Etme Durumu Arasındaki İlişkinin Ki Kare Analizi Sonuçları

\begin{tabular}{|c|c|c|c|c|c|}
\hline & \multicolumn{2}{|c|}{$\begin{array}{c}\text { Gelirin Bir Kısmını } \\
\text { Tasarruf Etme Durumu }\end{array}$} & \multirow{2}{*}{$\begin{array}{l}\text { Pearson } \\
\text { Ki-Kare }\end{array}$} & \multirow[b]{2}{*}{$\mathbf{p}$} \\
\hline & & Evet & Hayır & & \\
\hline \multirow{2}{*}{$\begin{array}{l}\text { Temel Düzey Finansal } \\
\text { Okuryazarlık }\end{array}$} & Düşük & $72(\% 59,5)$ & $49(\% 40,5)$ & \multirow[t]{2}{*}{15,767} & \multirow[t]{2}{*}{0,001} \\
\hline & Yüksek & $246(\% 78,3)$ & $68(\% 21,7)$ & & \\
\hline \multirow{2}{*}{$\begin{array}{l}\text { İleri Düzey Finansal } \\
\text { Okuryazarlık }\end{array}$} & Düşük & $17(\% 68,8)$ & $77(\% 31,2)$ & \multirow[t]{2}{*}{5,158} & \multirow[t]{2}{*}{0,23} \\
\hline & Yüksek & $150(\% 78,5)$ & $41(\% 21,5)$ & & \\
\hline
\end{tabular}


Elde edilen bulgulara göre Temel düzey finansal okuryazarlık bakımından P değeri 0,05'ten düşük olduğu için iki değişken arasında anlamlı bir ilişki olduğu gözlemlenmiştir. Temel düzey finansal okuryazarlığı yüksek olan bireylerin \%78,3'ünün gelirlerinin bir kısmını tasarruf ettiği görülmektedir. Bireylerin gelirlerinin bir kısmını tasarruf etme durumları ile ileri düzey finansal okuryazarlıkları arasındaki ilişkiye bakıldığında, yapılan ki kare analizinde P değeri 0,05'ten düşük olduğu için elde edilen bulguların anlamlı olduğu görülmüştür. İleri düzey finansal okuryazarlığı yüksek olan bireylerin \%78,5'inin gelirlerinin bir kısmını tasarruf ettikleri görülmektedir. Gerek temel düzey ve gerekse ileri düzey finansal okuryazarlık düzeyi arttıkça bireylerin tasarruf etme eğilimlerinin arttığı söylenebilir.

Son olarak bireylerin temel düzey ve ileri düzey finansal okuryazarlık düzeyleri ile tasarruf yapma oranları arasındaki ilişki Ki kare ile test edilmiştir. Hipotezler aşağıdaki gibidir:

Ho: Tasarruf yapma oranı ile temel finansal ve ileri düzey okuryazarlık ile bağlantılı değildir.

$\mathbf{H}_{3}$ : Tasarruf yapma oranı ile temel düzey ve ileri düzey finansal okuryazarlık ile bağlantılıdır.

$\mathbf{H}_{0}$ : Tasarruf yapma oranı ileri düzey finansal okuryazarlık ile bağlantılı değildir.

$\mathbf{H}_{4}$ : Tasarruf yapma oranı ileri düzey finansal okuryazarlık ile bağlantılıdır.

Tablo 16. Temel Düzey ve İleri Düzey Finansal Okuryazarlık ile Tasarruf Yapma Oranı Arasındaki İlişkinin Ki Kare Analiz Sonuçları

\begin{tabular}{|c|c|c|c|c|c|c|}
\hline & \multicolumn{3}{|c|}{ Tasarruf Yapma Oranı } & \multirow{2}{*}{$\begin{array}{l}\text { Pearson } \\
\text { Ki-Kare }\end{array}$} & \multirow[b]{2}{*}{$\mathrm{p}$} \\
\hline & & $\% 10-$ ve alt1 & $\% 10-20$ & \%20'den fazla & & \\
\hline \multirow{2}{*}{$\begin{array}{l}\text { Temel Düzey Finansal } \\
\text { Okuryazarlık }\end{array}$} & Düşük & $43(\% 43,9)$ & $37(\% 37,8)$ & $18(\% 18,4)$ & \multirow[t]{2}{*}{1,330} & \multirow[t]{2}{*}{0,514} \\
\hline & Yüksek & $115(\% 41,2)$ & $97(\% 34,8)$ & $67(\% 24)$ & & \\
\hline \multirow{2}{*}{$\begin{array}{l}\text { Illeri Düzey Finansal } \\
\text { Okuryazarlık }\end{array}$} & Düşük & $102(\% 48,1)$ & $65(\% 30,7)$ & $45(\% 21,2)$ & \multirow[t]{2}{*}{7,985} & \multirow[t]{2}{*}{0,018} \\
\hline & Yüksek & $57(\% 34,1)$ & $70(\% 41,9)$ & $40(\% 24)$ & & \\
\hline
\end{tabular}

Temel düzey finansal okuryazarlık ile tasarruf yapma oranı arasındaki ilişkiye bakıldığında, $\mathrm{P}$ değeri 0,05'ten büyük olduğu için elde edilen bulguların anlamlı olmadığı gözlemlenmiştir. İleri düzey finansal okuryazarlık ile tasarruf oranları arasındaki ilişkiye bakıldığında, P değeri 0,05 'ten düşük olduğu için elde edilen bulguların anlamlı olduğu söylenebilir. Elde edilen bulgulara bakıldığında, ileri düzey finansal okuryazarlığı yüksek olan bireylerin \%41'inin tasarruflarını \%10 ile \%20 arasında, \% 24'ünün tasarruflarını \% 20'den fazla, \%34'ünün ise tasarruflarının $\% 10$ ve altındaki gelirlerini tasarruf ettikleri tespit edilmiştir. Elde edilen bulgular ışığında, finansal okuryazarlık ile tasarruf arasında genel anlamda anlamlı bir ilişki olduğunu, bireylerin gerek temel düzey gerekse ileri düzey finansal okuryazarlıkları arttıkça tasarruf etme durumlarının arttığını, tasarruf etme oranlarının ise temel düzey finansal okuryazarlık ile anlamlı bir ilişkisi olmadığı fakat ileri düzey finansal okuryazarlık ile anlamlı bir ilişkisi olduğu söylenebilir. Nihai olarak doğruluğu sınanan hipotezlere ilişkin sonuçlar aşağıda Tablo 17 'de özetlendiği gibidir.

Tablo 17. Hipotezlere İlişkin Sonuçlar

\begin{tabular}{|l|c|c|}
\hline \multicolumn{1}{|c|}{ Hipotezler } & Kabul & Red \\
\hline $\begin{array}{l}\text { H1: Temel düzey ve ileri düzey finansal okuryazarlık düzeyleri cinsiyette } \\
\text { göre istatistiksel olarak farklılık göstermektedir. }\end{array}$ & $\checkmark$ & \\
\hline $\begin{array}{l}\text { H2: Temel düzey ve ileri düzey finansal okuryazarlık düzeyleri akademik } \\
\text { ve idari personele göre istatistiksel olarak farklllık göstermektedir. }\end{array}$ & $\checkmark$ & \\
\hline H3: Temel düzey ve ileri düzey finansal okuryazarlık düzeyleri eğitim & $\checkmark$ & \\
\hline
\end{tabular}




\begin{tabular}{|l|c|c|}
\hline durumunu göre istatistiksel olarak farklılık göstermektedir. & & \\
\hline $\begin{array}{l}\text { H4: Gelirin bir kısmını tasarruf etme durumu temel düzey ve ileri düzey } \\
\text { finansal okuryazarlık düzeyine göre istatistiksel olarak farklılık } \\
\text { göstermektedir. }\end{array}$ & $\checkmark$ & \\
\hline $\begin{array}{l}\text { H5: Tasarruf yapma oranı temel düzey ve ileri düzey finansal } \\
\text { okuryazarlık düzeyine göre istatistiksel olarak farklılık göstermektedir. }\end{array}$ & $\checkmark$ & \\
\hline
\end{tabular}

\section{SONUÇ}

Cinsiyetin temel düzey ve ileri düzey finansal okuryazarlık üzerinde anlamlı bir farklılık yaratıp yaratmadığını ölçmek amacıyla yapılan bağımsız örneklem $t$ testi sonuçlarına göre temel düzey finansal okuryazarlık bakımından cinsiyet ile finansal okuryazarlığın anlamlı bir farklılık göstermediği; İleri düzey finansal okuryazarlık bakımından cinsiyet anlamlı bir farklılık olduğu tespit edilmiştir. Yani cinsiyet açısından ileri düzey finansal okuryazarlık farklılık arz etmektedir. Bunun önemli ölçüde erkek personelden kaynaklandığı görülmüştür.

Akademik ve idari personel açısından temel ve ileri düzey finansal okuryazarlığın test edilmesi neticesinde ileri düzey finansal okuryazarlık açısından akademik ve idari personelin farklılaşma derecesi \%95 önem seviyesinde $\mathrm{p}$ değeri 0,138 gibi bir değerle anlamsız çıkmıştır. Temel düzey finansal okuryazarlık açısından anlamlı bir farklılık görülmüştür. Akademik personel temel düzeyde finansal okuryazarlık eğilimleri açısından idari personele oranla daha bilinçli olduğu görülmüştür.

Finansal okuryazarlık değişkeninin alt boyutlarından olan temel okuryazarlık düzeyinin eğitim durumuna göre istatistiksel olarak anlamlı bir farklılık gösterdiği de tespit edilmiştir. Eğitim durumu açısından temel finansal okuryazarlık düzeyi ortalamaları incelendiğinde, en düşük finansal okuryazarlık ortalamasının lise $(2,63)$ eğitimine sahip olanların; en yüksek ise yüksek lisans $(3,54)$ ve doktora $(3,51)$ eğitimine sahip olanların olduğu gözlemlenmiştir. İleri düzey finansal okuryazarlığın da 0.010 gibi bir değerle \%95 önem düzeyinde anlamlı bir farklılık sergilediği görülmüştür.

Yapılan LSD testi sonuçlarına bakıldığında LSD testi sonuçlarında lisenin 0.02 gibi bir değerle yüksek lisanstan ve 0.01 gibi bir değerle de doktoradan \%99 önem düzeyinde farklılaştığ1 gözükmektedir. Benzer bir şekilde yüksek lisansında lise 'den 0.02 doktoranın liseden 0,01 düzeyinde farklılaştığı gözükmektedir. Yani temel düzey finansal okuryazarlık açısından yüksek lisans ve doktora eğitimi görmüş akademik ve idari personelin lise düzeyinde eğitim görmüş personele oranla daha fazla temel düzey finansal okuryazarlık becerilerine sahip oldukları görülmüştür. İleri düzey finansal okuryazarlık açısından bakıldığında LSD sonuçları yine üniversitenin lisenin üniversiteden 0.02 gibi bir değerli 0.045 değerli yüksek lisanstan ve 0.03 gibi bir değerlerde doktoradan farklılaşttğ 1 gözükmekte yine üniversitenin liseden 0.02 yüksek lisansın liseden 0.45 doktoranın da liseden 0.03 olarak farklılaştı gözükmektedir. Yani üniversite yüksek lisans ve doktora eğitimi görmüş Akademik ve idari personelin ileri düzey okuma yazma becerileri lise düzeyinde eğitim görmüş akademik ve idari personelden daha fazla olduğu söylenebilir.

Finansal okuryazarlığın ileri seviyesi ile gelirin bir kısmını tasarruf etme durumu arasında yapılan ki-kare analizi sonuçlarına göre finansal okuryazarlığın ileri düzeyi ile gelirin bir kısmını tasarruf etme arasında oldukça yüksek düzeyde $(\% 75,5)$ anlamlı bir farklılığın ortaya çıktığı görülmektedir. Bu durumda finansal okuryazarlık düzeyi yükseldikçe gelirin bir kısmını tasarruf etme eğiliminin artacağı öngörüsünü doğrulamaktadır. Temel düzey finansal okuryazarlık ve gelirin bir kısmını tasarruf etme durumu arasında $(\% 78,3)$ oldukça yüksek düzeyde anlamlı bir farklılığın bulunduğu gözlemlenmiştir. Bu sonuç temel düzeyde de olsa 
finansal okuryazarlık düzeyinin gelirin bir kısmını tasarruf etme eğilimini artırdığını göstermektedir. Ortaya çıkan bulgulara göre finansal okuryazarlık düzeyi temel düzeyde de olsa ileri düzeyde de olsa katılımcların gelirinin bir kısmını tasarruf etme eğiliminde olduğunu gösterir.

Bireylerin temel düzey finansal okuryazarlıkları ile gelirin bir kısmını tasarruf etme durumları arasındaki ilişki Ki Kare Analizi ile incelendiğinde, temel düzey finansal okuryazarlı̆̆ı yüksek olan bireylerin \%78'inin gelirlerinin bir kısmını tasarruf ettiği görülmektedir. Bireylerin gelirlerinin bir kısmını tasarruf etme durumları ile ileri düzey finansal okuryazarlıkları arasındaki ilişkiye bakıldığında, ileri düzey finansal okuryazarlı̆̆ yüksek olan bireylerin \%78 oranında gelirlerinin bir kısmını tasarruf ettikleri görülmektedir. Gerek temel düzey ve gerekse ileri düzey finansal okuryazarlık düzeyi arttıkça bireylerin tasarruf etme eğilimlerinin arttığ1 söylenebilir. Elde edilen bulgulara bakıldığında, ileri düzey finansal okuryazarlığı yüksek olan bireylerin \%41'inin tasarruflarını \%10 ile \%20 arasında, \% 24'ünün tasarruflarını \% 20'den fazla, \%34'ünün ise tasarruflarının \%10 ve altındaki gelirlerini tasarruf ettikleri tespit edilmiştir.

Çalışmada "Temel Düzey Finansal Okuryazarlık ve İleri Düzey Finansal Okuryazarlık" başlıkları altında incelenen sorulara katılımcıların verdiği cevaplar yüksek düzeyde finansal okuryazar bir örnekleme sahip olunduğunu göstermektedir. Akademik ve idari personelin unvan, yaş, eğitim düzeyi gelir, ekonomik gelişmeler ile finansal gelişmeleri izleme durumu, gelirin bir kısmını tasarruf etme durumu ve tasarruflarına muhafaza etme durumları farklılıklar göstermektedir. Bu çalışma ile Kılıç vd. 2015; Tuna ve Ulu, 2016, Tüfekçi, Erdoğan vd. 2017'nin bulgularına benzer şekilde pek çok demografik özellik ile finansal okuryazarlık düzeyi arasında anlamlı ilişki tespit edilmiştir. Bu araştırmadan yola çıkarak geniş örneklemlerle birçok akademik ve idari personelin finansal okuryazarlık düzeyini belirlemek ve finansal eğitime ve tasarrufa olan ihtiyacı noktasında bir eğitime ihtiyaçları olup olmadığını belirlemek için daha detaylı çalışmalar yapılmalıdır.

\section{KAYNAKÇA}

Araz, T. (2012). Financial Literacy and Credit Card Arrears. Boğaziçi University Instittute for Graduate Studies in Social Sciences, Master of Arts, İstanbul.

Barmaki, N. (2015). Üniversitesi Öğrencilerinin Finansal Okuryazarlık Düzeylerini Belirlemeye Yönelik Bir Araştırma: Hacettepe Üniversitesi Örneği. Hacettepe Üniversitesi Sosyal Bilimler Enstitüsü Doktora Tezi, Ankara.

Barut, A. Çam, A V. (2015). Finansal Okuryazarlık Düzeyi ve Davranışları: Gümüşhane Üniversitesi Ön lisans Öğrencileri Üzerinde Bir Araştırma." Küresel İktisat ve İşletme Çalışmaları Dergisi, 4 (7), 63-72.

Baysa, E., Karaca, S. S. (2016). Finansal Okuryazarlık ve Banka Müşteri Segmentasyonları Üzerine Bir Uygulama. Muhasebe Finansman Dergisi, 14 (21), 122.

Biçer, E., Altan B. (2016). Üniversite Öğrencilerinin Finansal Okuryazarlık ile İlgili Tutum ve Davranışlarının Değerlendirilmesi. Atatürk Üniversitesi Sosyal Bilimler Enstitüsü Dergisi, 20 (4), 1501-1517.

Blalock, L. L, Tiller, Vicky, M., Pamel. A. (2004). They Get You Out Of Courage: Persistent Deep Poverty Among Former Welfare-Reliant Women. Familiy Relations, 127-137.

Chen, H. Volpe R, P, (2002), Gender Differences in Personnel Financial Literacy, 289-307.

Chlouba, T., Simkova, M. Nemcova, Z, (2011). Application for Education of Financial Literacy. Procedia - Social And Behavioral Sciences, 28, 370-373. 
Contuk, F. Y. (2018). Üniversite Öğrencilerinin Finansal Okuryazarlık Durumunu Etkileyen Faktörler Üzerine Bir Araştırma: Muğla Sıtkı Koçman Üniversitesi Örneği. Muhasebe ve Finansman Dergisi, (77), 115-136.

Coşkun, S. (2016). Üniversite Öğrencilerinin Finansal Davranış ve Tutumlarının Belirlenmesi: Finansal Okuryazarlık Algıları Üzerine Bir Araştırma. İnsan ve Toplum Bilimleri Araştırmaları Dergisi, 5 (7) , 2247-2258.

Çil Koçyiğit, S. Şeremet, G. G., Altunay, R. Sağllk Yönetimi Bölümü ve İşletme Bölümü Ögrencilerinin Finansal Okuryazarlık Düzeylerinin Belirlenmesi: Gazi Üniversitesi Örneği. Gülcan, B. ve Sağlam Arı, G. (Ed). Prof. Dr. Erkan Öngel'e Armağan Çok Disiplinli Çalışmalar içinde (ss. 126- 139) Ankara: Detay Yayıncılık.

Çömlekçi, İ. (2017). İslami Finansal Okuryazarlık Düzeyinin Belirlenmesi: Katılım Bankaların Müşterileri Üzerinde Bir Araştırma". Elektronik Sosyal Bilimler Dergisi, 16 (63), 1423-1439.

Dağdelen, T. (2017). Finansal Okuryazarlı Düzeyinin Belirlenmesi ve Aydın Ilindeki Serbest Muhasebeci Mali Müşavirler Üzerine Bir Uygulama". Adnan Menderes Üniversitesi Sosyal Bilimler Enstitüsü İşletme Anabilim Dalı Yüksek Lisans Tezi, Aydın.

Disney, R. Gathergood, J. (2013). Financial Literacy And Consumer Credit Portfolios. Journal Of Banking And Finance", (37), 2246-2254.

Ergün, B. Ahün, A. Ergün, E, (2016) Finansal Okuryazarlık: İşletme Öğrenciler Üzerine Bir Çalışma". Uluslararası Sosyal Araştırmalar Dergisi, 7 (34), 847-863.

Fettahoğlu, S (2015). Hane halkının Finans Eğitimi ve Finansal Okuryazarlık Düzeyleri Üzerine Kocaeli'nde Bir Araştırma. Muhasebe Finansman Dergisi, 14 (122), 101-106.

Gaisina, S. Kaidarova, L. (2017). "Financial Literacy of Rural Population as a Determinant of Saving Behavior in Kazakhstan". Rural Sustannabilnty Research, 38 (333), ISSN - 2256-0939.

Gutnu, M. M., Cihangir, M. (2015). Finansal Okuryazarlık: Osmaniye Korkut Ata Üniversitesi Personeli Üzerinde Bir Araştırma, Akademik Sosyal Araştırmalar Dergisi, (3), 1-15.

Güler, E. (2015). Hane Halkının Finansal Okuryazarlık Düzeyinin Belirlenmesi Üzerine Bir Araştırma: Sakarya İli Örneği. Sakarya Üniversitesi, Sosyal Bilimler Enstitüsü Yüksek Lisans Tezi, Sakarya.

Karaağaç, A. (2015). Finansallaşma Sürecinde Finansal Okuryazarlık. İstanbul Üniversitesi Sosyal Bilimler Enstitüsü Yüksek Lisans Tezi, İstanbul.

Kaya, A. (2015). Kobi Yöneticilerinin Finansal Okuryazarlık Düzeylerinin Belirlenebilmesine Yönelik Bir Araştırma: İzmir İli Örneği. İzmir Kâtip Çelebi Üniversitesi Sosyal Bilimler Enstitüsü Yüksek Lisans Tezi, İzmir.

Kılıç, Y, Ata, H. A., İbrahim H, (2015). Finansal Okuryazarlık: Üniversite Öğrencilerine Yönelik Bir Araştırma. Muhasebe Finansman Dergisi, 14 (66), 129-154.

Lusardi, A. (2008). Financial Literacy: An Essential Tool for Informed Consumer Choice?. NBER Working Paper No. 14084, 1-29.

Lusardi, A. and Tufano, P. (2009). Debt Literacy, Financial Experiences, and Overindebtedness. National Bureau of Economic Research, NBER Working Paper Series, 1-46.

Lusard1, A. Klapper, L. Panos, G, A. (2013) Financial Literacy and Its Consequences: Evidence from Russia during the Financial Crisis. Journal Of Banking \& Finance, 37 (10), October, 3904-3923.

Lusardi, A. Mitchell, O, S (2008).Planning and Financial Literacy: How Do Women Fare", Working Paper, 13750. 
Lusardi, A. Tufano, P . (2009 a.b). Debt Literacy, Financial Experiences and Overindebtedness", Working Paper 14808.

Özen, E. Kaya, Z. (2015). Finansal Okuryazarlık Seviyesinin Ölçülmesi: Üniversite Öğrencileri Üzerine Bir Araştırma. 19. Finans Sempozyumu, 21-24 Ekim 2015, Çorum.

Öztürk, E, (2014). Finansal Okuryazarlık ve Para Yönetimi: Süleyman Demirel Üniversitesi Akademik Personel Üzerine Bir Uygulama, Süleyman Demirel Üniversitesi Sosyal Bilimler Enstitüsü Yüksek Lisans Tezi, Isparta.

Saraç, E. (2014). Finansal Okuryazarlık ve Dumlupınar Üniversitesi Öğrencilerinin Finansal Okuryazarlı Düzeylerinin Belirlenmesi Üzerine Bir Araştırma. Dumlupınar Üniversitesi Sosyal Bilimler Enstitüsü Yüksek Lisans Tezi, Kütahya.

SPK ve Dünya Bankası, (2012), Türkiye Finansal Yeterlilik Araştırması, Sonuç Raporu. SPK ve Dünya Bankası http://www.spk.gov.tr/duyurugoster.aspx? aid=2012116 \&subid=0\&ct=f (Erişim Tarihi: 01. 01. 2014).

Şamiloğlu, F. Kahraman, Y. Emre, B, H. (2016). Finansal Okuryazarlık Araştırması: Erciyes Üniversitesi Öğrencileri Üzerinde Bir Uygulama. Uluslararası Yönetim İktisat ve İsletme Dergisi, (ICAFR 16 Özel Sayıs1), 308-321.

Tamaskova, H. Mohelska, H. Nemcova, Z. (2011). Issues of Financial Literacy Education. Procedia - Social and Behavioral Sciences, 28, 365-369.

Tamaskova, H, Mohelska, H, Nemcova, Z. (2013). Issues of Financial Literacy Education, $\begin{array}{llll}\text { Procedia } \quad \text { "Socialand } & \text { Behavioral } & \text { Sciences,28:, } & \end{array}$ http://www.researchgate.net/profile/Hana Tomaskova/publication/235744601 Issues of Financial_Literacy_Education/links/00b495287ddd075a01000000.pdf (Erişim Tarihi: 20. 04. 2013).

Temizel, F. Bayram, F, (2010). Finansal Okuryazarlık: Anadolu Üniversitesi İktisadi ve İdari Bilimler Fakültesi (İ̈BF) Öğrencilerine Yönelik Bir Araştırma". Cumhuriyet Üniversitesi İktisadi ve İdari Bilimler Dergisi, 12 (1), 73-87.

Tosun, A. E. (2016). Lise Öğrencilerinin Finansal Okuryazarlık Düzeyi Üzerine Bir Alan Araştırması. Karadeniz Teknik Üniversitesi Sosyal Bilimler Enstitüsü Yüksek Lisans Tezi, Trabzon.

Tuna, G, Ulu, M. O. (2016). Üniversite Öğrencilerinin Finansal Okuryazarlık Düzeylerini Etkileyen Faktörlerin Belirlenmesi İşletme Bölümü Öğrencileri Üzerine Bir Araştırma. Uluslararası Yönetim İktisat ve İşletme Dergisi, (ICAFR 16 Özel Sayısı), 128-141.

Tüfekçi B., Erdoğan S., Karaca, S. S., Seçgin N. (2017). Finansal Okuryazarlık Bilgi Düzeyinin Ölçülmesi: İşletme Bölümü Öğrencileri Üzerine Bir Uygulama. Uluslararası İşletme, Ekonomi ve Yönetim Perspektifleri Dergisi, 2 (7), 58-72.

Ünal, S. Düğer, Y. Selim, S. C. (2015). Ekonomi Okuryazarlığı ve Kredi Kartı Tutumunun Rasyonel Kredi Kartı Kullanımına Etkisi Dumlupınar Üniversitesi Tavşanlı MYO Örneği. Eskişehir Osmangazi Üniversitesi İ̈BF Dergisi, 10 (1), 31-52.

Yardımcıoğlu, M Yörük, A. (2016). Türkiye'deki Finansal Okuryazarlığın ve Finansal Farkındalığı Durumu. Muhasebe ve Vergi Uygulamaları Dergisi, 9 (2), 173-208.

Yılmaz, V, Tuncay, M, (2017). Finansal Liberalizasyonun Tasarruf ve Yatırım Üzerine Etkisi: Türkiye Örneği". Atatürk Üniversitesi İktisadi ve İdare Bilimler Dergisi, 26 (3-4), 345-363.

http://www.fo-der.org, (Erişim Tarihi: 21. 04. 2019). 